\title{
Variables associated with cognitive, behavioral and emotional development: a cohort of schoolchildren
}

\author{
Adriana Martins Saur - Universidade de São Paulo, Ribeirão Preto, São Paulo, Brasil \\ Sabrina Kerr Bullamah Correia - Universidade de São Paulo, Ribeirão Preto, São Paulo, Brasil \\ Heloisa Bettiol - Universidade de São Paulo, Ribeirão Preto, São Paulo, Brasil \\ Marco Antonio Barbieri - Universidade de São Paulo, Ribeirão Preto, São Paulo, Brasil \\ Sonia Regina Loureiro - Universidade de São Paulo, Ribeirão Preto, São Paulo, Brasil
}

Variáveis associadas aos desenvolvimentos cognitivo, comportamental e emocional: uma coorte de escolares

\begin{abstract}
Resumo
O presente trabalho objetivou identificar possíveis variáveis associadas com o desenvolvimento cognitivo, comportamental e emocional de uma coorte de crianças em idade escolar, com base em variáveis biológicas (idade, sexo e peso ao nascer) e socioeconômicas (estado civil, educação materna e paterna, ocupação do chefe de família, status socioeconômico e número de membros da família). Foram avaliadas 790 crianças nascidas em uma coorte de Ribeirão Preto (SP), Brasil, aos 10/11 anos de idade. Para a avaliação cognitiva utilizou-se o Teste de Raven e para a avaliação emocional e comportamental usou-se o Questionário de Capacidades e Dificuldades. Por meio de análise de regressão logística multivariada (IC 95\%), verificou-se que: 1) baixa escolaridade materna foi associada a problemas comportamentais, emocionais e baixo desempenho cognitivo; 2) sexo feminino foi um fator de proteção contra problemas de comportamento e 3) baixo peso ao nascer e prematuridade não foram associados com as variáveis investigadas.

Palavras-chave: Desenvolvimento infantil, Comportamento infantil, Fatores de risco, Estudos de coortes, Desenvolvimento cognitivo.
\end{abstract}

\begin{abstract}
This study aimed to identify possible variables associated with cognitive, behavioral and emotional development in a cohort of school children, based on biological (sex, gestational age and birth weight) and socioeconomic variables (marital status, maternal and paternal education, occupation of head of household, socioeconomic status, and number of household members). We evaluated 790 children born in a cohort of Ribeirão Preto (SP), Brazil, with 10/11 years of age. The Raven Test was used for cognitive assessment and the Strengths and Difficulties Questionnaire was utilized for emotional and behavioral assessment. By means of multivariate logistic regression analysis (CI 95\%) we found that: 1) low maternal schooling was associated with behavioral and emotional problems and poor cognitive function, 2) being female was considered as a protective factor against behavioral problems and 3) low birth weight and prematurity were not associated with the outcomes investigated.

Keywords: Child development, Child behavior, Risk factors, Cohort studies, Cognitive development.
\end{abstract}

Variables asociadas a los desarrollos cognitivo, conductual y emocional: una cohorte de escolares

\begin{abstract}
Resumen
Este estudio objetivó identificar las posibles variables asociadas con el desarrollo cognitivo, comportamental y emocional de una cohorte de niños en edad escolar basado en variables biológicas (edad, sexo y peso al nacer) y socioeconómicas (estado civil, nivel educacional materno y paterno, ocupación del jefe del hogar, estatus socioeconómico y número de miembros de la familia). Fueron evaluados 790 niños nacidos en una cohorte de Ribeirão Preto (SP-Brasil), a los 10/11 años de edad. Para la evaluación cognitiva se utilizó el Test de Raven, y para la evaluación emocional y comportamental se usó el Cuestionario de Capacidades y Dificultades. Por medio del análisis de regresión multivariada (IC 95\%) se verificó que: 1) baja escolaridad materna fue asociada a problemas comportamentales, emocionales y bajo desempeño cognitivo; 2) el sexo femenino fue un factor de protección contra problemas de comportamiento y 3 ) el bajo peso al nacer y la prematuridad no fueron asociados con las variables investigadas. Palabras clave: Desarrollo infantil, Conducta infantil, Factores de riesgo, Estudios de cohortes, Desarrollo cognitivo.
\end{abstract}

\section{Introduction}

Knowledge about the possible risk factors present in the trajectory of a child is essential for the deployment of resources aimed at reducing of their incidence and the minimizing of their effects. Three types of risk conditions have been considered: a) established risk related to defined medical disorders, especially those of genetic origin; b) biological risk related to pre-, peri- and postnatal events; and c) environmental risk including socioeconomic, educational and family conditions (Masten \& Gerwitz, 2006).

Among the main biological risk factors, low birth weight and prematurity are particularly important. These 
are considered to be key indicators of health and chances of survival among babies since they still are the main factors involved in infant mortality (Organização Mundial da Saúde, 1994). Parallel to these biological conditions is a gamut of environmental variables that can affect the development of a child, aggravating or even attenuating the risk condition of prematurity and low birth weight. Among the main variables involved in environmental context, the literature emphasizes socioeconomic factors such as maternal and paternal schooling and the economic classification of the family (Farooqi, Hägglöf, Sedin, Gothefors, \& Serenius, 2007; Hayes \& Sharif, 2009; Kelly, Nazroo, McMunn, Boreham, \& Marmot, 2001; Milligan, 2010; Theodore et al., 2009).

Several studies have focused on the impact of prematurity and low birth weight and their association with environmental risks (Aarnoudse-Moens, Weisglas-Kuperus, Goudoever, \& van Osterlaan, 2009; Anderson \& Doyle, 2008; Bhutta, Cleves, Casey, Cradock, \& Anand, 2002). Many of these studies have detected greater losses in school, physical, cognitive and behavioral performance among low birth weight and/or premature children compared to children born at term and of normal weight; possibly extending to psychological and social development during adolescence and/or adult life (Delobel-Ayoub et al., 2009; Indredavik, Vik, Heyerdahl, Kulseng, \& Brubakk, 2005; Johnson, 2007; Rodrigues, Mello, \& Fonseca, 2006). However, impairment of cognitive, behavioral and emotional performance is not the only possible outcome. Several studies have observed positive results, with children exposed to both biological and socioeconomic risk factors, yet demonstrating no loss in at least some of these areas (Espírito Santo, Portuguez, \& Nunes, 2009; Farooqi et al., 2007; Rodriguez, Silva, Bettiol, Barbieri, \& Rona, 2011; Theodore et al., 2009; Winchester et al., 2009). This indicates the presence of protective mechanisms that can modify the response of an individual in a risky or adverse context.

In view of these data, we cannot be deterministic regarding which risk factors can have a negative effect on developmental outcomes. Thus, early identification of child development deficits can be helpful in developing intervention strategies directed at minimizing the impact of certain risk factors on the trajectory of these children (Sameroff \& Fiese, 2005).

Within this context, the objective of the present study was to identify variables associated with the cognitive, behavioral and emotional performance of a cohort of school age children evaluated at 10/11 years of age on the basis of biological and socioeconomic variables.

\section{Method}

\section{Characterization of the study situation}

The present study is part of a broader project directed at the evaluation of the impact of birth size on physical, affective, cognitive and psychological development of Brazilian children. The study refers to the data of the 1994 birth cohort in the city of Ribeirão Preto, SP, and to the follow-up evaluation of the same cohort in 2004/2005 (Cardoso et al., 2007; Silva et al., 2011). Ribeirão Preto is a city with a population of 583,842 inhabitants in 2010, (Instituto Brasileiro de Geografia e Estatística, 2011) located in the interior of São Paulo State, Southeast region of the country, considered to be a wealthy and industrialized region.

\section{Data collection}

Information was collected about all births that occurred at the 10 maternity hospitals of Ribeirão Preto from April to August 1994, considering the absence of seasonality regarding birth distribution, (Bettiol et al., 1998) for a total of 3663 babies. Losses represented less than $5 \%$ of the births during this period, due to refusal to participate and discharge from hospital before interview. Twin births $(n=84,2.3 \%)$ and children born to mothers who were not residents of Ribeirão Preto $(n=733,20.5 \%)$ were excluded from the study and the final number of babies studied was 2846. The data were obtained by interviewing the puerperae in order to obtain sociodemographic information and information about pregnancy, delivery and the newborn.

Since one of the initial objectives of the broader project was to assess the impact of birth weight on certain outcomes, the birth weight variable was used to define the sample, which consisted of five weight groups: very low birth weight (VLBW, $<1500 \mathrm{~g}$ ), low birth weight (LBW, 1500 to $2499 \mathrm{~g}$ ), insufficient birth weight (IBW, 2500 to $2999 \mathrm{~g}$ ), normal birth weight (NBW, 3000 to $4249 \mathrm{~g}$ ), and high birth weight (HBW, $\geq 4250 \mathrm{~g}$, referring to infants whose birth weight was at least two standard deviations above the mean for the population). Due to the higher mortality during the first year of life, the infants in the weight ranges with the smallest numbers of newborns (VLBW, LBW and HBW) (Goldani, Barbieri, Rona, Silva, \& Bettiol, 2004) were oversampled in order to increase the power 
of the study. In the other weight ranges, one in every three parents or guardians were randomly invited to participate.

The second stage of evaluation of the cohort at school age (follow-up study) was started in 2004. Of the 2846 children participating in the first phase, $1138(40 \%)$ were found by consulting the general student registry compiled by the State Secretary Office of Education, including public and private schools. The parents or guardians responsible for the children were informed about the reasons of the study and asked to give written informed consent for the participation of their children. Of the 1138 children located, data from $790(68.7 \%)$ were available.

\section{Ethics:}

The study was approved by the Research Ethics Committee of the University Hospital, Faculty of Medicine of Ribeirão Preto, University of São Paulo (HCFMRP-USP). No incentives were provided to the schools or to the student participants.

\section{Instruments and measurements:}

- Cognitive evaluation was performed by applying the Raven's Coloured Progressive Matrices Test (test of non-verbal intelligence) standardized for Brazilian children aged 5 to 12 years (Angelini, Alves, Custódio, Duarte, \& Duarte, 1999). The results were dichotomized into two classificatory groups: below-average intellectual level or deficient ( $<25$ th percentile) and average or above average intellectual level ( $\geq 25$ th percentile).

- Behavioral and emotional assessment was conducted using the Portuguese (Brazilian) version of the Strengths and Difficulties Questionnaire (SDQ), designed to screen behavioral problems of children and adolescents between 4 and 16 years of age (available at www. sdqinfo.com) (Goodman, 1997). The SDQ contains four scales that screen psychiatric symptoms (emotional symptoms, behavioral problems, hyperactivity, and peer problems) and a scale that reflects pro-social behavior. Scores are assigned on each of these scales $(0,1$ or 2 , in which "Somewhat true" is always scored as 1 , but the scoring of "False" and "True" varies with the item) and scores for the four symptoms scales are summed up to provide a "total difficulties score" ranging from 0 to 40, with higher scores indicating more behavioral problems. The cut-off note for behavioral problems is a total score $>16$ and scores below this value are classified as normal. Emotional evaluation was performed using the emotional symptoms scale of the SDQ, with the cut-off note for emotional difficulties being a score $\geq 5$. Parents, teachers or the youths themselves could answer the questionnaire. In the present study, a parent report version was used.

- The characteristics of the children and of the family were obtained by interviewing the mothers at the time of the infant's birth. The following information was recorded: infant's sex, birth weight (grams), gestational age (weeks), maternal and paternal schooling (low schooling $\leq 8$ years of study and high schooling $>8$ years of study), maternal marital status (married or with no companion), head of household occupation (non-manual, skilled and semi-skilled manual and unskilled), and number of household members ( $\leq 4$ and $>4)$. Information about the socioeconomic level of the families was obtained at school age (more privileged economic classes - levels A1, A2, B1 and B2 and underprivileged economic classes - levels $\mathrm{C} 1, \mathrm{C} 2, \mathrm{D}$ and $\mathrm{E}$ ), according to a standard Brazilian Questionnaire (Associação Brasileira de Empresas de Pesquisa, 2008).

\section{Statistical treatment of the data:}

- Weighting: since the sampling regarding the collection carried out in 2004 was not equiprobabilistic in view of the fact that VLBW, LBW and HBW children had a greater proportional participation in the initial sample, it was necessary to correct these estimates by weighting the data, taking into consideration the different probabilities of selection of each birth weight group (Silva et al., 2011). This is a statistical strategy used to correct possible selection biases and to increase the power of detecting differences in the comparison of these groups to the remaining ones.

- Data analysis: we used the logistic regression analysis model with the aid of the PROC SURVEYLOGISTIC feature of the SAS 9.0 software, which takes the weightings into account. Univariate and multiple regression analyses were used to estimate the associations between the characteristics of the child/family and the cognitive, behavioral and emotional performance of the children, with a 95\% confidence interval $(95 \%$ CI). The crude odds ratio $(\mathrm{OR})$ was calculated in a first step, and the adjusted odds ratio $(A O R)$ was then calculated in order to control for possible confounding factors. The adjustment regarding the multiple regression model took into 
account all the independent variables (sex, birth weight, gestational age, marital status, socioeconomic level, father's occupation and number of household members). The reference category was chosen as, hypothetically, the group of lowest risk, except for birth weight, for which the reference was low birth weight.

\section{Results}

Data regarding the characterization of the children and their families are listed in Table 1. With respect to the biological characteristics, there was an equal distribution between sexes and a predominance of babies born at term with normal birth weight. Regarding the socioeconomic characteristics, most of the parents were married, the predominant educational level of father and mother was zero to eight years of study, and most of them reported manual occupations. Most families belonged to underprivileged economic classes and the predominant number of household members in the children's families was up to four persons.

Univariate and multiple logistic regression analysis were carried out in order to identify possible variables associated with cognitive performance as determined by the Raven Test, as shown in table 2. In non-adjusted analysis, normal birth weight was a protective factor for cognitive performance $(O R=0.50,95 \% C I 0,20-0,83)$, whereas preterm birth $(O R=1.86,95 \%$ CI $1.17-2.97)$, low maternal $(O R=4.34,95 \% C I 2.16-8.75)$ and paternal schooling (OR=2.31, 95\% CI $1.25-4.26)$, skilled/ semi-skilled occupation of the family head $(O R=4.36$, 95\% CI $1.67-11.38$ ) and unskilled/unemployed situation $(O R=7.08,95 \%$ CI $2.55-19.68)$, less privileged economic classification $(O R=3.64,95 \%$ CI $1.74-7.62)$, and five or more household members $(O R=1.71,95 \%$ CI 1.08 - 2.73) were risk factors for impaired cognitive performance. In adjusted analysis, the only variable that remained associated with cognitive performance was maternal schooling, indicating that children of mothers with low schooling (zero to eight years of study) were almost at a three-fold higher risk of being classified intellectually as below average or deficient compared to children of mothers with high schooling (nine or more years of study).

Table 3 presents the crude and adjusted results regarding the variables associated with behavioral performance, as assessed by the SDQ. In the non-adjusted model, female sex $(O R=0.69,95 \% C I 0.51-0.94)$ and normal birth weight $(O R=0.66,95 \%$ CI $0.46-0.96)$ were protective factors against behavioral problems. In contrast, low maternal $(O R=2.70,95 \%$ CI $1.89-3.87)$ and paternal schooling $(O R=2.71,95 \%$ CI $1.85-3.95)$, skilled/semi-skilled manual occupation $(O R=2.18,95 \%$ CI 1.39 - 3.43) and unskilled/occupation/unemployment of the family head $(O R=3.30,95 \% C I 1.89-5.73)$, a less privileged economic classification $(O R=2.51$, $95 \%$ CI $1.71-3.69)$, and five or more household members $(O R=1.73,95 \% C I 1.24-2.42)$ were risk factors for impaired behavioral performance. After adjustment, the variables that continued to be associated were female sex as a protective factor $(O R=0.61,95 \%$ CI 0.41 - 0.89) and low maternal schooling as a risk factor for behavioral problems $(O R=1.83,95 \%$ CI 1.12 - 3.00).

Results for the variables associated with the emotional indicators assessed by the emotional symptoms scale of the SDQ are presented on Table 4. Crude analysis showed that normal birth weight was a protective factor against emotional problems (OR-0.64, 95\% CI $0.44-0.93)$, while low maternal schooling $(O R=2.53$, $95 \% C I 1.83-3.53)$ and paternal schooling $(O R=1.78$, $95 \%$ CI $1.26-2.50)$, skilled/semi-skilled manual occupation (OR-2.33, 95\% CI 1.55 - 3.49) and unskilled manual occupation/unemployment of the family head (OR-2.58, 95\% CI $1.54-4.32)$ and belonging to less privileged economic classes $(O R=2.26,95 \%$ CI 1.60 - 3.19) were risk factors. After adjustment, only low maternal schooling $(O R=2.16,95 \%$ CI 1.37 - 3.42) continued to be associated with emotional symptoms.

\section{Discussion}

Some relevant aspects can be pointed out regarding the variables associated with cognitive, behavioral and emotional performance identified in the present study: a) low maternal schooling was a risk factor for the three outcomes assessed: b) boys had a higher chance to present behavioral difficulties than girls; and c) birth weight and gestational age were not found to be associated with any of the indicators considered.

Preterm birth was a risk factor for cognitive performance and birth weight was associated with the three outcomes studied only in non-adjusted analysis, with the association disappearing after adjustment for all variables. These data suggest that the children of the present cohort, even when exposed to biological risk factors such as low birth weight and prematurity, did not show impaired performance, indicating the presence of possible protective factors related to sociodemographic characteristics during their developmental trajectory. It is interesting to consider the socioeconomic profile 
Table 1. Biological characteristics of the children and socioeconomic characteristics of their families

\begin{tabular}{lc}
\hline Biological characteristic of the children & $F(\%$ weighted $)$ \\
\hline Sex & $1418(50.8)$ \\
Male & $1374(49.2)$ \\
Female & $275(9.8)$ \\
Birth weight groups & $729(26.1)$ \\
Low birth weight $(<2499 \mathrm{~g})$ & $1752(62.8)$ \\
Insufficient birth weight $(2500-2999 \mathrm{~g})$ & $36(1.3)$ \\
Normal birth weight $(3000-4249 \mathrm{~g})$ & \\
High birth weight $(\geq 4250 \mathrm{~g})$ & $336(12.0)$ \\
Gestational age & $2456(88.0)$ \\
Preterm $(<37$ weeks $)$ & \\
At term $(\geq 37$ weeks $)$ &
\end{tabular}

Socioeconomic conditions of the families

Maternal marital status

Married or in consensual union

$2290(86.3)$

No companion

$364(13.7)$

Mother's schooling

Low (0 to 8 years of study)

$1629(64.1)$

High (9 or more years of study)

$914(35.9)$

Father's schooling

Low (0 to 8 years of study)

$1480(63.6)$

High (9 or more years of study)

$846(36.4)$

Father's occupation

Non-manual

Skilled and semi-skilled manual

1651 (62.6)

Unskilled manual and unemployed

$455(17.3)$

Economic classification

Classes A1, A2, B1 and B2

$731(26.2)$

Classes C1, C2, D and E

Number of household members

1 to 4 members

$1845(69.2)$

5 or more members

$820(30.8)$ 
Table 2. Variables associated with cognitive performance assessed by the Raven Test

\begin{tabular}{|c|c|c|}
\hline Cognitive performance & $\begin{array}{l}\text { Crude OR } \\
(95 \% C I)\end{array}$ & $\begin{array}{c}\text { Adjusted OR } \\
(95 \% C I)\end{array}$ \\
\hline \multicolumn{3}{|l|}{ Sex } \\
\hline Male & reference & reference \\
\hline Female & $1.02(0.65-1.60)$ & $1.10(0.63-1.96)$ \\
\hline \multicolumn{3}{|l|}{ Birth weight groups } \\
\hline Low birth weight (<2499 g) & reference & reference \\
\hline Insufficient birth weight $(2500-2999 \mathrm{~g})$ & $0.71(0.39-1.29)$ & $0.77(0.36-1.64)$ \\
\hline Normal birth weight $(3000-4249$ g) & $0.50(0.29-0.83)^{*}$ & $0.61(0.31-1.21)$ \\
\hline High birth weight $(\geq 4250 \mathrm{~g})$ & $1.11(0.35-2.95)$ & $2.67(0.65-11.04)$ \\
\hline \multicolumn{3}{|l|}{ Gestational age } \\
\hline Preterm (<37 weeks) & $1.86(1.17-2.97)^{*}$ & $1.40(0.76-2.61)$ \\
\hline At term ( $\geq 37$ weeks) & reference & reference \\
\hline \multicolumn{3}{|l|}{ Maternal marital status } \\
\hline Married or in consensual union & reference & reference \\
\hline No companion & $1.34(0.72-2.47)$ & $0.92(0.38-2.24)$ \\
\hline \multicolumn{3}{|l|}{ Mother's schooling } \\
\hline Low (0 to 8 years of study) & $4.34(2.16-8.75)^{*}$ & $2.73(1.03-7.39)^{*}$ \\
\hline High (9 or more years of study) & reference & reference \\
\hline \multicolumn{3}{|l|}{ Father's schooling } \\
\hline Low (0 to 8 years of study) & $2.31(1.25-4.26)^{*}$ & $0.82(0.38-1.72)$ \\
\hline High ( 9 or more years of study) & reference & reference \\
\hline \multicolumn{3}{|l|}{ Father's occupation } \\
\hline Non-manual & reference & reference \\
\hline Skilled and semi-skilled manual & $4.36(1.67-11.38)^{*}$ & $1.89(0.63-5.72)$ \\
\hline Unskilled manual and/or unemployed & $7.08(2.55-19.68)^{*}$ & $2.45(0.71-8.44)$ \\
\hline \multicolumn{3}{|l|}{ Economic classification } \\
\hline Classes A1, A2, B1 and B2 & reference & reference \\
\hline Classes C1, C2, D and E & $3.64(1.74-7.62)^{*}$ & $1.83(0.78-4.30)$ \\
\hline \multicolumn{3}{|l|}{ Number of household members } \\
\hline 1 to 4 members & reference & reference \\
\hline 5 or more members & $1.71(1.08-2.73) *$ & $1.23(0.68-2.23)$ \\
\hline
\end{tabular}

* Significant association (logistic regression analysis, $p \leq 0.05$ )

of the cohort, which showed that almost $37 \%$ of the mothers and fathers had a good schooling level (nine or more years of study), most fathers $(83 \%)$ reported skilled occupations, most families $(86 \%)$ were in a stable union, and $26 \%$ belonged to privileged economic classes. These conditions possibly acted as protective factors capable of minimizing the impact of prematurity and of low birth weight on some children, as pointed out in some studies reporting similar results (Anderson \& Doyle, 2008; Espírito Santo et al., 2009; Rodriguez et al., 2011). However, the present results disagree from those observed in other studies in which behavioral deficits were observed in low birth weight and/or premature children (Aarnoudse-Moens et al., 2009; Bhutta et al., 2002; Delobel-Ayoub et al., 2009; Johnson, 2007). However, these studies were conducted 
Table 3. Variables Associated with behavioral performance assessed by the Strengths and Difficulties Questionnaire

\begin{tabular}{|c|c|c|}
\hline Behavioral performance & $\begin{array}{l}\text { Crude OR } \\
(95 \% C I)\end{array}$ & $\begin{array}{c}\text { Adjusted OR } \\
(95 \% C I)\end{array}$ \\
\hline \multicolumn{3}{|l|}{ Sex } \\
\hline Male & reference & reference \\
\hline Female & $0.69(0.51-0.94)^{*}$ & $0.61(0.41-0.89)^{*}$ \\
\hline \multicolumn{3}{|l|}{ Birth weight groups } \\
\hline Low birth weight (<2499 g) & reference & reference \\
\hline Insufficient birth weight $(2500-2999 \mathrm{~g})$ & $0.75(0.48-1.16)$ & $0.86(0.49-1.53)$ \\
\hline Normal birth weight $(3000-4249 \mathrm{~g})$ & $0.66(0.46-0.96)^{*}$ & $0.72(0.43-1.23)$ \\
\hline High birth weight $(\geq 4250 \mathrm{~g})$ & $0.40(0.16-1.01)$ & $0.56(0.17-1.89)$ \\
\hline \multicolumn{3}{|l|}{ Gestational age } \\
\hline Preterm (<37 weeks) & $1.10(0.78-1.56)$ & $0.89(0.54-1.45)$ \\
\hline At term ( $\geq 37$ weeks) & reference & reference \\
\hline \multicolumn{3}{|l|}{ Maternal marital status } \\
\hline Married or in consensual union & reference & reference \\
\hline No companion & $1.31(0.83-2.04)$ & $1.18(0.67-2.10)$ \\
\hline \multicolumn{3}{|l|}{ Mother's schooling } \\
\hline Low (0 to 8 years of study) & $2.70(1.89-3.87)^{*}$ & $1.83(1.12-3.00)^{*}$ \\
\hline High ( 9 or more years of study) & reference & reference \\
\hline \multicolumn{3}{|l|}{ Father's schooling } \\
\hline Low (0 to 8 years of study) & $2.71(1.85-3.95)^{*}$ & $1.43(0.86-2.40)$ \\
\hline High ( 9 or more years of study) & reference & reference \\
\hline \multicolumn{3}{|l|}{ Father's occupation } \\
\hline Non-manual & reference & reference \\
\hline Skilled and semi-skilled manual & $2.18(1.39-3.43)^{*}$ & $1.17(0.64-2.15)$ \\
\hline Unskilled manual and/or unemployed & $3.30(1.89-5.73)^{*}$ & $1.07(0.50-2.28)$ \\
\hline \multicolumn{3}{|l|}{ Economic classification } \\
\hline Classes A1, A2, B1 and B2 & reference & reference \\
\hline Classes C1, C2, D and E & $2.51(1.71-3.69)^{*}$ & $1.57(0.91-2.70)$ \\
\hline \multicolumn{3}{|l|}{ Number of household members } \\
\hline 1 to 4 members & reference & reference \\
\hline 5 or more members & $1.73(1.24-2.42)^{*}$ & $1.46(0.98-2.19)$ \\
\hline
\end{tabular}

* Significant association (logistic regression analysis, $p \leq 0.05$ )

on groups with distinct characteristics from those of the group evaluated in the present study, primarily consisting of more premature children and of lower birth weight. With respect to this question, review studies in the literature have argued about the difficulty in comparing results due to the existence of extreme methodological variability regarding the categories of analysis for the same variable, the diverse ages at the time of evaluation, the different inclusion criteria and the different instruments used for evaluation (Bhutta et al., 2002; Milligan, 2010). This diversity impairs the estimate of the real effect of preterm birth and low birth weight on cognitive and/or behavioral development, indicating the need for a relative approach to comparisons with the literature, especially regarding the methodological aspects. 
Table 4. Variables associated with emotional indicators assessed by the Emotional Symptoms Scale of the Strengths and Difficulties Questionnaire

\begin{tabular}{|c|c|c|}
\hline Emotional indicators & $\begin{array}{l}\text { Crude OR } \\
(95 \% C I)\end{array}$ & $\begin{array}{c}\text { Adjusted OR } \\
(95 \% C I)\end{array}$ \\
\hline \multicolumn{3}{|l|}{ Sex } \\
\hline Male & reference & reference \\
\hline Female & $1.28(0.95-1.72)$ & $1.06(0.75-1.52)$ \\
\hline \multicolumn{3}{|l|}{ Gestational age } \\
\hline Preterm $(<37$ weeks $)$ & $0.98(0.70-1.39)$ & $0.79(0.50-1.26)$ \\
\hline At term ( $\geq 37$ weeks) & reference & reference \\
\hline \multicolumn{3}{|l|}{ Birth weight groups } \\
\hline Low birth weight $(<2499 \mathrm{~g})$ & reference & reference \\
\hline Insufficient birth weight $(2500-2999 \mathrm{~g})$ & $1.02(0.65-1.59)$ & $1.05(0.60-1.82)$ \\
\hline Normal birth weight (3000 - 4249 g) & $0.64(0.44-0.93)^{*}$ & $0.69(0.41-1.14)$ \\
\hline High birth weight $(\geq 4250 \mathrm{~g})$ & $0.41(0.17-0.95)^{*}$ & $0.64(0.22-1.89)$ \\
\hline \multicolumn{3}{|l|}{ Maternal marital status } \\
\hline Married or in consensual union & reference & reference \\
\hline No companion & $1.10(0.70-1.71)$ & $0.94(0.55-1.63)$ \\
\hline \multicolumn{3}{|l|}{ Mother's schooling } \\
\hline Low (0 to 8 years of study) & $2.53(1.83-3.53)^{\dagger}$ & $2.16(1.37-3.42)^{*}$ \\
\hline High ( 9 or more years of study) & reference & reference \\
\hline \multicolumn{3}{|l|}{ Father's schooling } \\
\hline Low (0 to 8 years of study) & $1.78(1.26-2.50)^{\dagger}$ & $0.79(0.48-1.28)$ \\
\hline High (9 or more years of study) & reference & reference \\
\hline \multicolumn{3}{|l|}{ Father's occupation } \\
\hline Non-manual & reference & reference \\
\hline Skilled and semi-skilled manual & $2.33(1.55-3.49)^{*}$ & $1.64(0.97-2.77)$ \\
\hline Unskilled manual and/or unemployed & $2.58(1.54-4.32)^{*}$ & $1.18(0.59-2.35)$ \\
\hline \multicolumn{3}{|l|}{ Economic classification } \\
\hline Classes A1, A2, B1 and B2 & reference & reference \\
\hline Classes C1, C2, D and E & $2.26(1.60-3.19)^{*}$ & $1.51(0.93-2.46)$ \\
\hline \multicolumn{3}{|l|}{ Number of household members } \\
\hline 1 to 4 members & reference & reference \\
\hline 5 or more members & $1.31(0.94-1.82)$ & $1.05(0.70-1.56)$ \\
\hline
\end{tabular}

* Significant association (logistic regression analysis, $p \leq 0.05$ )

Special attention should be paid to the age at child evaluation since various studies have observed that possible behavioral losses due to the condition of prematurity and low birth weight may be minimized over the years (Anselmi et al., 2010; Zwicker \& Harris, 2010). Within this context, since the psychological evaluations were performed at school age, it is plausible to propose that these deficits may have been attenuated with time.
The results regarding the association of maternal schooling with developmental outcomes agree with several studies showing that the educational level of the parents was a relevant factor for cognitive, behavioral and/or emotional outcome of the children (Hayes \& Sharif, 2009; Johnson, 2007; Kelly et al., 2001; Milligan, 2010; Sameroff \& Fiese, 2005; Theodore et al., 2009). These studies reported that, when the social 
circumstances are unfavorable, the risk of children presenting deficits long their development may increase. In this respect, improvement of the environment and of socioeconomic risk factors may act as protective mechanisms that can minimize possible adversities in the path of development of these children.

However, in a Brazilian study whose objective was to determine the association between variables of the family context and risk of emotional/behavioral disorders, (Ferrioli, Marturano, \& Puntel, 2007) also conducted in Ribeirão Preto and using the same instrument for evaluation (SDQ), socioeconomic level was not found to be associated with problems of this type. We believe that this result may have been due to methodological differences in the composition of the sample and in the instruments used.

In another Brazilian study with a similar methodology, maternal schooling was found not to be associated with the behavioral or emotional outcome of the child, in contrast to what was observed in the present study (Rodriguez et al., 2011). However, other sociodemographic variables such as paternal age, maternal marital status and socioeconomic level showed association with behavioral aspects and emotional indicators, leading to conclusions similar to those obtained in the present study, in which the socioeconomic and demographic conditions were found to be better predictors of mental health problems than biological factors such as low birth weight and prematurity.

The observation that boys presented greater behavioral difficulties than girls also agrees with previous studies published in the Brazilian (Anselmi et al., 2010; Cury \& Golfeto, 2003) and international literature (Anderson \& Doyle, 2008; Indredavik et al., 2005). However, in a Brazilian study, (Rodriguez et al., 2011) sex was not found to be associated with behavioral performance on the total difficulties scale of the SDQ, in contrast to the result obtained here, although in the cited study boys were found to be at higher behavioral risk regarding externalizing problems (as determined based on the conduct and hyperactivity problems scales). This difference can be explained by considering the geographic location of the populations studied: the present study was conducted in a city considered to be wealthy and industrialized, in one of the more privileged regions in the country (Southeast), while the cited study was conducted in a city in the Northeast region, considered to be among the poorest in the country. Regarding the emotional indicators, the sex variable was not found to be associated with problems of this nature in either study.
One of the main contributions of the present investigation is that this is one of the few cohort studies in Brazil that detected an association of biological and socioeconomic variables in developmental domains regarding cognitive, behavioral and emotional aspects. Considering that Brazil is a developing country, studies of this type are scarce and more extensive studies can contribute to the deployment of intervention strategies aiming at the reduction of the occurrence of behavio$\mathrm{ral} / \mathrm{emotional}$ problems among children of school age. As such, it is recommended that new studies be undertaken with more diverse sampling of the population in different regions of Brazil, as the region in which the present study was developed (southeast region) is considered the most favorable in the country.

Among the limitations of this study, at least three can be highlighted: a) the evaluation of behavioral and emotional performance was based on data provided by a single source, i.e., the parents or guardians, while the use of evaluation based on more informants is recommended; b) it was not possible to obtain information about the mental health of the parents, a factor that may be associated with psychological problems in children of school age; and c) the instrument used for behavioral and emotional assessment is a screening tool for problems of this nature and cannot be considered to be a diagnostic instrument.

\section{References}

Aarnoudse-Moens, C. S. H., Weisglas-Kuperus, N., Goudoever, J. B. V., \& van Osterlaan, J. (2009). Meta-analysis of neurobehavioral outcomes in very preterm and/or very low birth weigth children. Pediatrics, 124, 717-728.

Anderson, P., \& Doyle, L. W. (2008). Cognitive and educational deficits in children born extremely preterm. Seminars in Perinatology, 32, 51-58.

Angelini, A. L., Alves, I. C. B., Custódio, E. M., Duarte, W. F., \& Duarte, J. L. M. (1999). Manual - Matrizes Progressivas Coloridas de Raven: escala especial. São Paulo: Centro Editor de Testes e Pesquisas em Psicologia.

Anselmi, L., Menezes, A. M. B., Barros, F. C., Hallal, P. C., Araujo, C. L., Domingues, M. R. et al. (2010). Early determinants of attention and hyperactivity problems in adolescents: The 11- year follow-up of the 1993 Pelotas (Brazil) birth cohort study. Caderno de Saúde Pública, 26, 1954-1962. 
Associação Brasileira de Empresas de Pesquisa (2008). Questionário de Classificação Sócio-Econômico. Disponível em: http://www.abep.org. Acessado em: 10 abril 2012.

Bettiol, H., Barbieri, M. A., Gomes, U. A., Andrea, M., Goldani, M. Z., \& Ribeiro, E. R. O. (1998). Saúde perinatal em Ribeirão Preto, SP, Brasil, 1994: metodologia e algumas características da população estudada. Revista de Saúde Pública, 32, 18-28.

Bhutta, A. T., Cleves, M. A., Casey, P. H., Cradock, M. M., \& Anand, K. J. (2002). Cognitive and behavioral outcomes of school-aged children who were born preterm: a meta-analysis. JAMA, 288, 728-737.

Cardoso, V. C., Simões, V. M. F., Barbieri, M. A., Silva, A. A. M., Bettiol, H., Alves, M. T. S. S. B., et al. (2007). Profile of three Brazilian birth cohort studies in Ribeirão Preto, SP and São Luís, MA. Brazilian Journal of Medical and Biological Research, 40, 1165-1176.

Cury, C. R., \& Golfeto, J. H. (2003). Questionário de capacidades e dificuldades (SDQ): um estudo em escolares de Ribeirão Preto. Revista Brasileira de Psiquiatria, 25, 139-145.

Delobel-Ayoub, M., Arnaud, C., White-Koning, M., Casper, M. C., Pierrat, V., Garel, M., et al. (2009). Behavioral problems and cognitive performance at 5 years of age after very preterm birth: the EPIPAGE study. Pediatrics, 123, 1485-1492.

Espírito Santo, J. L., Portuguez, M. W., \& Nunes, M. L. (2009). Cognitive and behavioral status of low birth weigth preterm children raised in a developing country at preschool age. Jornal de Pediatria, 85 , $35-41$.

Farooqi, A., Hägglöf, B., Sedin, G., Gothefors, L., \& Serenius, F. (2007). Mental health and social competencies of 10- to 12-year-old children born at 23 to 25 weeks of gestation in the 1990s: a Swedish national prospective follow-up study. Pediatric, 120, 118-133.

Ferrioli, S. H. T., Marturano, E. M., \& Puntel, L. P. (2007). Contexto familiar e problemas de saúde mental infantil no Programa de Saúde da Família. Revista de Saúde Pública, 41, 251-259.

Goldani, M. Z., Barbieri, M. A., Rona, R. J., Silva, A. A., \& Bettiol, H. (2004). Increasing pre-term and low birth weight rates over time and their impact on infant mortality in south-east Brazil. Journal of Biosocial Science, 36, 177-188.

Goodman, R. (1997). The strengths and difficulties questionnaire: a research note. Journal of Child Psychology and Psychiatry, 38, 581-586.

Hayes, B., \& Sharif, F. (2009). Behavioral and emotional outcome of very low birth weight infants: literature review. The Journal of Maternal-Fetal \& Neonatal Medicine, 22, 849-856.

Indredavik, M. S., Vik, T., Heyerdahl, S., Kulseng, S., \& Brubakk, A. M. (2005). Psychiatric symptoms in low birth weight adolescents, assessed by screening questionnaires. European Child and Adolescent Psychiatry, 14, 226-236.

Instituto Brasileiro de Geografia e Estatística (2011). Disponível: http://www.censo2010.ibge.gov.br. Acessado em: 21 março 2011.

Johnson, S. (2007). Cognitive and behavioural outcomes following very preterm birth. Seminars in Fetal and Neonatal Medicine, 12, 363-373.

Kelly, Y. J., Nazroo, J. Y., McMunn, A., Boreham, R., \& Marmot, M. (2001). Birthweight and behavioural problems in children: a modifiable effect? International Journal of Epidemiology, 30, 88-94.

Masten, A. S., \& Gerwitz, A. H. (2006). Vulnerability and resilience in early child development. In K. McCartney \& D. Phillips (Eds.), Blackwell handbook of early childhood development (pp. 22-43). Chichester: Blackwell.

Milligan, D. W. A. (2010). Outcomes of children born very preterm in Europe. Archives of Disease in Childhood. Fetal Neonatal Edition, 95, F234-F240.

Organização Mundial da Saúde. (1994). CID-10: Classificação estatística internacional de doenças e problemas relacionados à saúde. São Paulo: EDUSP.

Rodrigues, M., Mello, R. R., \& Fonseca, S. C. (2006). Dificuldade de aprendizagem em escolares de muito baixo peso ao nascer. Jornal de Pediatria, 82, 6-14.

Rodriguez, J. D. M., Silva, A. A. M., Bettiol, H., Barbieri, M. A., \& Rona, R. (2011). The impact of perinatal and socioeconomic factors on mental health problems of children from a poor Brazilian city: A longitudinal study. Social Psychiatry and Psychiatric Epidemiology, 46, 381-391. 
Sameroff, A. J, \& Fiese, B. H. (2005). Models of development and developmental risk. In C. H. Zeanah Jr. (Ed.), Handbook of infant mental health (2nd ed., p. 3). New York: The Guilford Press.

Silva, A. A. M., Barbieri, M. A., Cardoso, V. C., Batista, R. F., Simões, V. M., Vianna, E. O., et al. (2011). Prevalence of non-communicable diseases in Brazilian children: Follow-up at school age of two brazilian birth cohorts of the 1990's. BMC Public Health, 11, 486-499.

Theodore, R. F., Thompson, J. M. D., Waldie, K. E., Becroft, D. M. O., Robinson, E., Wild, C. J., et al. (2009). Determinants of cognitive ability at 7 years: a longitudinal case-control study of children born small-for-gestational age at term. European Journal Pediatric, 168, 1217-1224.

Winchester, S. B., Sullivan, M. C., Marks, A. K., Doyle, T., DePalma, J., \& McGrath, M. M. (2009). Academic, social, and behavioral outcomes at age 12 of infants born preterm. Western Journal of Nursing Research, 31, 853-871.

Zwicker, J. G., \& Harris, S. R. (2010). Quality of life of formerly preterm and very low birth weight infants from preschool age to adulthood: a systematic review. Pediatrics, 121, e366-e376.

Recebido em: 07/04/2013

Reformulado em: 21/10/2013

Aprovado em: 18/11/2013

Sobre os autores:

Adriana Martins Saur é psicóloga, mestre e doutora em Ciências (Programa de Psicologia) pela Faculdade de Filosofia, Ciências e Letras de Ribeirão Preto da Universidade de São Paulo, pós-doutoranda do Departamento de Puericultura e Pediatria da FMRP-USP e docente do Centro Universitário Barão de Mauá. Atua nas áreas de Avaliação Psicológica e Psicologia do Desenvolvimento.

Sabrina Kerr Bullamah Correia é psicóloga, mestre em Ciências (Programa de Psicologia) pela Faculdade de Filosofia, Ciências e Letras de Ribeirão Preto da Universidade de São Paulo, especialista em Terapia Cognitiva pelo Instituto de Terapia Cognitiva (ITC).

Heloisa Bettiol é pediatra, professora associada do Departamento de Puericultura e Pediatria da FMRP-USP e coordenadora do Programa de Pós-Graduação em Saúde da Criança e do Adolescente da FMRP-USP, atuando nas áreas de saúde materno-infantil, epidemiologia perinatal, mortalidade infantil e origem desenvolvimentista da saúde e da doença.

Marco Antonio Barbieri é pediatra, professor titular aposentado e coordenador do Núcleo de Estudos da Saúde da Criança e do Adolescente do Departamento de Puericultura e Pediatria da FMRP-USP. Estuda o crescimento humano, epidemiologia perinatal, mortalidade infantil e origens desenvolvimentais da saúde e da doença.

Sonia Regina Loureiro é psicóloga, professora doutora do Departamento de Neurociências e Ciências do Comportamento da FMRP-USP, docente dos Cursos de Pós-Graduação em Saúde Mental e Psicologia (USP) e coordenadora do Serviço de Avaliação Psicológica junto ao HCFMRP-USP. Desenvolve atividades de pesquisa com instrumentos de avaliação, tendo como foco principal a saúde mental infantil.

Contato com os autores:

Rua Jaqueira 81, Ribeirão Preto, São Paulo, CEP 14040-270

E-mail: adrianasaur@yahoo.com.br.

Psico-USF, Bragança Paulista, v. 19, n. 1, p. 131-141, jan./ abril 2014 
